\title{
...having people that will help you, that know the ropes and have walked that road before you': How does first in family status impact graduates in the employment field?
}

\author{
Sarah O'Shea ${ }^{1}$, Olivia Groves ${ }^{2}$ and Janine Delahunty ${ }^{3}$ \\ Corresponding author: Sarah O'Shea (sarah.oshea@curtin.edu.au) \\ ${ }^{1}$ Curtin University, Australia: http://orcid.org/0000-0002-8988-6674 \\ ${ }^{2}$ Curtin University, Australia \\ ${ }^{3}$ University of Wollongong, Australia
}

\begin{abstract}
Increasing competitiveness in the graduate employment field combined with growing numbers of degree bearing applicants means that gaining employment after completing university studies can be a lengthy and complex undertaking. This is even more the case for students who do not have ready access to the social or family capital often required for successful employment, such as those who are first in their family to attend university. This article reveals hidden tensions within the post-graduation employment market when this is negotiated without the benefit of necessary capitals required to do so successfully. Drawing on interview and survey data from recent first in family graduates and alumni in Australia, the ways in which they negotiated employment was explored. This exposed an alternative perspective on graduate employment that highlights the somewhat 'hidden' inequities and unfair expectations within a hyper competitive job market. Participants' written and spoken reflections reveal the ways in which the graduate landscape is far from being an 'even playing field'. The perspectives presented contribute to broader understanding about the difficulties of moving towards desired employment goals or social mobility particularly when intangible relational and personal capitals are needed. Such insights are needed to inform both policy and practice globally, particularly as nation states come to terms with the repercussions of the current health crisis.
\end{abstract}

Keywords:

Graduate employment, first in family students, social theory, Bourdieu

\section{Introduction}

This paper reports on research conducted in Australia which drew upon the experiences of alumni and graduating students navigating the post-graduation employment landscape. Globally, there has been a significant increase in the number of students undertaking university study and graduating with a degree qualification (Marginson, 2016; OECD, 2001). Undoubtedly, this increase in formal university qualifications has led to a greater diversity of students attending university and also has clear implications for graduate employment. For example, the rise in student numbers has not been matched by employer demand, resulting in an oversupply of graduates and intensified competition for employment across the world, including in Europe, North America, China and India (Allen et al., 2013; Purcell et al., 2013; Roulin \& Bangerter, 2013). Within Australia, the sheer volume of students graduating and their increased diversity has not been addressed in directed or targeted policy or 
practices. Hence, this study sought to consider qualitatively the postgraduate experiences of one such diverse cohort namely those students who are the first in their families to attend university.

An existing and comprehensive body of literature and research articulates the university experiences of students who are the first member of their family, and in some cases their community, to attend university. The term 'first in family' (FiF) is being used in this paper to refer to those students who are the first in their immediate family, including parents, partners, children and siblings, to undertake a higher-education qualification. The FiF student group is a growing cohort in university populations globally and are regarded as collectively encountering additional and often invisible obstacles as they move through university (Longwell-Grice et al., 2016; O'Shea et al., 2017). Even a superficial review of the existing literature points to how this student population is generally problematised as somehow disadvantaged compared to other higher education participants (Luzeckyj et al., 2011; Mehta, Newbold, \& O’Rourke, 2011; Spiegler \& Bednarek, 2013).

Within Australia, the statistical data relating to the FiF cohort is somewhat flawed, largely due to variances in data collection and issues around how Fif status is defined. Currently, Australian higher education institutions collect this data at enrolment by requesting the highest educational level of students' parents. Anecdotally students, particularly older students, have reported that this question is left unanswered as it is deemed to be unrelated to an individual's educational pursuits. Such ambiguity has led to a call for this status to be more explicitly extrapolated in equity data (Patfield, Gore, \& Weaver, 2020). What we do know is that approximately half the university student population in Australia (51\%) are derived from FiF backgrounds (defined by parental educational levels) which is close to the OECD mean average of 53\% (Spiegler \& Bednarek, 2013). Yet enrolments at individual universities, particularly those in regional locations, often exceed this percentage with some institutions anecdotally reporting up to $70 \%$ of their student population as the first in their families to attend. The large numbers of Fif students means that this population merits close research attention, particularly in terms of their educational outcomes and employment destinations.

While the literature indicates the ways in which FiF students have a differentiated experience during transition into and through studies, compared to their second or third generation peers (Pascarella et al., 2004; Spiegler \& Bednarek, 2013) it is less clear what happens once this cohort leaves university and enters the graduate job market. The research outlined in this paper was designed to provide insights from the perspectives of two groups: those who were near completion or graduates anticipating future employment; and FiF alumni reflecting upon their transition into the work environment. Drawing upon interviews and surveys, this unique combination of perspectives provides a 'close-up' analysis of the 'hidden tensions' that participants reflected upon. Based upon students' richly descriptive insights, some recommendations are offered which are particularly pertinent in this pandemic period with anticipated high rates of unemployment and underemployment, combined with potentially greater levels of university participation. To contextualise the data that follow, the next sections consider the characteristics of the employment landscape with specific reference to the experiences of students from more diverse backgrounds.

\section{Context}

\section{The contemporary graduate marketplace}

The graduate employment market has become increasingly competitive both within Australia and on a more global scale due to massification of higher education and the changed world of work (Roulin \& Bangerter, 2013). National graduate surveys conducted across a range of countries indicate significant numbers of graduates remain unemployed in the short and medium term; that is, they are available for employment but unable to find full-time, part-time or casual employment (QILT, 2018). For example, in the UK, approximately $5.1 \%$ of graduate survey respondents $(n=412,300)$ were unable to find paid work (HESA, 2017), while in Australia this figure was $13 \%$ of respondents $(n=120,564)$, or a total of 15,673 graduates (QILT, 2018). Positively, most of these people do manage 
to find employment within 3-5 years with unemployment rates for graduates in the medium term much lower in NZ (3\%), the US (3\%) and Australia (3.6\%) (NCES, 2018a, 2018b; QILT, 2018; Universities New Zealand, 2018).

Despite eventually obtaining employment, evidence suggests that many graduates are not fully utilising their knowledge, experience, skills and university qualifications in post-graduation employment. High numbers of employed graduates in Australia report that they are not being employed in occupations requiring 'a level of skill commensurate with a bachelor degree or higher' (QILT, 2019, p. 23). This situation is echoed in the UK, where $15 \%$ of graduates did not obtain a professional job in the medium term; instead graduates are over represented in sales and customerservice occupations (HESA, 2017). A reasonably high proportion of Australian students also report that their qualification was 'not at all important' (22.6\%) or 'not that important' (14.5\%) for their employment (QILT, 2019). Similarly, in the UK, the importance of graduates' qualification in gaining their current employment was ranked as 'not very important' (21.2\%) or 'not important' (15.5\%) (HESA, 2018).

While these statistics provide some insight into the contemporary job market, such surveys do not provide detail of who these people are or why they did not obtain degree relevant work straight after their studies. Navigating the postgraduate landscape is a complex venture, arguably exacerbated for those students who experience cumulative or multiple forms of disadvantage and are impacted by material or social factors. Within Australia, the likelihood of unemployment increases when a graduate is from multiple equity groups ${ }^{1}$. Such multiplicity informs the characteristics of employment, including sector, type of employer, role, contract and means of finding work (Richardson, Bennett, \& Roberts, 2016). Specifically, graduates from the top three socio-economic (SES) quartiles are estimated to be 1.2 times more likely to be employed than those from the bottom socio-economic quartile, with the latter also experiencing more tenuous work situations (Richardson et al., 2016). Indeed, the Australian study by Richardson and colleagues points to how graduates from many disadvantaged groups are generally clustered within the sub-fields of broad disciplines that are arguably regarded as lower-status occupations, most of which attract lower remuneration.

Without doubt, employment is a key reason for students to enter higher education: gaining a productive or rewarding job after graduation is an important outcome of completion. Within Australia and beyond, the call to 'widen participation' in the higher education sector and the associated participation targets, has resulted in a more diverse population of students encouraged to apply for university studies (Bradley et al., 2008). Yet, this focus on access has not necessarily been matched by a rigorous assessment of how these students fare post-graduation (Pitman et al., 2019). Whilst countries such as Australia, the UK and the US have all engaged in strategies designed to increase student participation rates, the focus on post-graduation targets, particularly for equity students, has lacked sustained or deep analysis.

The research detailed in this paper sought to investigate this graduate experience from the perspective of the actual learners. There is little research that focuses explicitly on the narratives of graduating students and alumni who are first in their families to attend university and as such, enter the post-graduate employment market. By providing details of this transition into employment, this paper contributes to the ways in which we prepare students from more diverse backgrounds for employment post-graduation.

\section{University and beyond: First in family equity student experiences}

To understand how FiF students experience the graduate landscape, it is necessary to first consider the ways in which university participation may have been experienced for this cohort. This is not to

\footnotetext{
${ }^{1}$ There are six identified equity groups: students from low socio-economic backgrounds; students with a disability, Aboriginal and Torres Strait Islander students, non-English speaking background students, rural and remote students and women studying in non-traditional areas
} 
say that all FiF students have similar experiences or contexts, but rather to acknowledge that this cohort may have differentiated experiences compared to their second or third generation peers. One way this difference is manifested is through sense of belonging, which may be less developed compared to learners who have a previous familial connection with the university. Ball, Davies, David and Reay (2002) explain that transgenerational family scripts or 'inheritance codes' (p. 57) play into a greater sense of entitlement to be a university student. When such educational memories are not present within the family, students may struggle to understand the inner workings of the institution. In previous research (O'Shea, 2016), this mismatch in belonging was described by commencing $\mathrm{FiF}$ as a form of uncertainty related to university language, expectations and protocols of behaviour (p. 62). Such variances may make the FiF cohort particularly vulnerable to attrition and disengagement from the university setting as attendance requires additional effort to understand the somewhat 'hidden' rules of engagement.

The shared rules and relationships that govern different social spaces or 'fields' can only be translated if an individual has access to particular forms of capital, which can be economic or cultural, the latter defined by family or social position (Bourdieu, 1986). The concept of capital has been rigorously applied to understandings of power and domination, and the social theorist, Pierre Bourdieu (1930-2002) has identified various forms, which include social, cultural and symbolic capital; with the latter generated though manifestations of prestige. Understanding how the university setting is constructed as a social space reveals how social reproduction can be played out in subtle and taken for granted ways. Drawing on the qualitative experiences of students who are from a greater diversity of backgrounds can then provide insights into how these institutions may act as a type of 'sorting machine' that selects students according to an implicit social classification and reproduces the same students according to an explicit academic classification (Naidoo, 2004, p. 459).

One example of this 'sorting machine' in action relates to participation in extracurricular activities whilst at university (Moreau \& Leathwood, 2006; Pollard, 2018). The uptake and selection of internships is reported as being lower for students from more financially disadvantaged backgrounds (Ashley et al., 2015). A key inhibitor to participating in these opportunities is the high economic cost of undertaking an internship, as many do not attract any remuneration (Montacute, 2018). Within Australia, approximately $87 \%$ of internships are unpaid (Interns Australia, 2018). Yet undertaking these types of work experience is increasingly recognised as a key resource for boosting employability and obtaining post-graduation employment (FYA, 2018). Undoubtedly, employers seek out employees who have had experience relevant to the professional field. However, the cost of participating in these activities makes them largely inaccessible to those with ongoing financial commitments, such as students with part-time work responsibilities or student-carers. Simply, learners from more affluent or financially stable backgrounds enjoy a greater choice of placements because they have greater resources to draw upon (Allen et al., 2013).

However, financial reasons are not the only rationale for individuals electing not to participate in these opportunities. Learners from more diverse backgrounds may not take advantage of internships as a result of inadvertently playing the degree 'game' according to outdated rules. Bathmaker, Ingram and Waller (2013) draw upon Bourdieu's concept of 'having a feel for the game' and relate this to post-graduate employability. To 'play the game' effectively within the employment field, learners increasingly require additional skills and knowledges beyond those provided solely through degree content. These are often 'soft skills' acquired through participating in additional extracurricular opportunities including internships and work placements. However, when students have limited exposure to the higher education field this may cause some to believe that success in employment is wholly dictated by their degree results, with sole focus on the degree at the expense of other opportunities to develop skills and knowledge. In other words, for students who may be the first in their families or from lower SES backgrounds, achieving high grades in the degree program may be considered to be the key ingredient to attaining future employability (Bathmaker et al., 2013). This perspective overlooks the volatility and expansion of the market, suggesting a fundamental mismatch between these learners' expectations and the realities of the graduate job market. 
Overall, the twenty-first century job market is both diverse and competitive with new and unanticipated work roles emerging all the time. However, in the most immediate period, an unforeseen disruption has occurred which further delineates and impacts upon this environment. The onset of the COVID-19 pandemic heralded transformations both in the capacity for people to actually work and the availability of jobs. The next section reflects upon the emerging trends in postgraduate employment as we navigate the current health crisis.

\section{Graduate employment in the age of pandemic}

COVID-19 has impacted every facet of life including the employment market, which is witnessing a massive global decline in the availability of work, resulting in escalating unemployment rates. This is a worldwide crisis and as a result, students at all stages of their education are experiencing some form of disadvantage, exacerbated by forced school closures, community lockdowns and also, ongoing economic uncertainty (Drane, Vernon \& O'Shea, 2020). However, in the midst of this pandemic it is the higher education sector that is recognised as providing possible routes during and beyond COVID, characterised as the 'engine rooms of prosperity' which provide the 'new ideas, new skills and new jobs to power the economic and social recovery' (Universities Australia, 2020, paragraph 11). Unfortunately, this is likely to be a long road back to recovery with three quarters of graduate employment in fields likely to be impacted by this crisis (Norton, 2020).

Akkermans, Richardson and Kraimer (2020) refer to COVID-19 as instigating a 'career shock' which is defined as a hugely disruptive or extraordinary event that causes long-term consequences to choices and planning related to careers. While the immediate repercussions of this event have been somewhat buffeted by the introduction of Government support payments in many countries (e.g. UK, Australia, Canada), this type of funding is simply a 'band aid' solution to address the most urgent events caused by mass unemployment. While still in the midst of this event, what we do know is that it is people aged 20-29 years that have borne the brunt of COVID, with reports that between March 14 and June 27 there was an $8 \%$ loss in payroll jobs for this age cohort (FYA, 2020, p. 24). Overall, the health dilemma has thrown into sharp relief how fragile work can be for many workers, across a large number of industries (FYA, 2020, p. 31).

COVID-19 had immediate impacts on the higher education system, commencing with changes to how employers engaged with students and the recruitment processes linked to graduate employment (Reidy, 2020). With the mass move to online learning, many universities have had to adapt, offering virtual internships and also, more expansive career advice including mental and health assistance. Undoubtedly it is those students with limited material, financial and familial resources that will be hardest hit by this epidemic. COVID-19 has exposed some of the most pervasive and underlying inequities in the education system (Drane et al., 2020). Those students who rely on casual part-time work to engage in their studies have felt the most immediate impact, but repercussions will also be apparent for graduates at all stages of their career. While the research outlined in this paper occurred prior to COVID-19, the areas of analysis may be usefully applied to this health crisis. The focus on how students qualitatively manage the transition to work and the ways in which their FiF status and additional equity demographics impact on this transition provides deeply descriptive insights into the nature of this trajectory. Purposely moving away from statistical evidence and instead focussing on student narrative provides unique understanding of what needs to change to improve graduate outcomes for equity learners generally.

\section{Methodology}

The research outlined in this paper was designed to specifically consider whether patterns of disadvantage persist after graduation (Richardson et al., 2016, p. 8). Research indicates how choices related to education including what to study and where to enrol, are highly differentiated (Edwards \& McMillan, 2015; Reay, 2016). These choices have been linked to class and social demarcations, with students from more disadvantaged backgrounds frequently choosing institutions which they 
feel are closer geographically and socially (Reay, David, \& Ball, 2001) and, similarly choosing career focus based on familiarity rather than aspirational fit (Shergold et al., 2020). If educational choices can be linked to students' access to economic and cultural resources, the question this research sought to explore was the ways in which demographic factors, such as first in family status, influence or impact graduate outcomes for certain student cohorts.

This Australian study occurred in 2019 and engaged with recent graduates, alumni and also key stakeholders to consider the ways in which graduate employment was considered (current students and stakeholders) and critically reflected upon (Alumni). This article focuses on the data collected with students and alumni ( $n=257)$, all of whom were first in their families to attend university, and addresses the overarching research questions: How do learners from intersecting equity categories enter the employment market, and how is this 'entry to employment' experienced at an individual qualitative level? This was a convenience sample with participants recruited through email sent via peak bodies, universities and student equity and support services. This approach to recruitment may have had implications for the participants who elected to be involved, targeting a cohort perhaps more highly engaged with their institution compared to others who may have disengaged due to disillusionment or disappointment in their student and postgraduate experience.

A total of $225 \mathrm{FiF}$ alumni completed a survey with questions ranging from seeking details about work experiences post-graduation through to perceived usefulness of the degree, personal changes since graduation and feelings of preparedness after completing their study. In addition to these open questions $(n=20)$ the survey also included 20 closed questions all of which included text boxes for additional details. The opportunity to include descriptive detail meant that the alumni surveys were very rich and detailed, including respondents from across age groups and also, disciplines as Table 1 demonstrates.

Table 1: Alumni - Distribution by Age/Gender and Discipline Area $\left(\mathbf{n}=\mathbf{2 0 4 ^ { 2 } )}\right.$

\begin{tabular}{|c|c|c|c|c|c|c|c|c|c|c|}
\hline $\begin{array}{l}\text { Age / } \\
\text { Gender }\end{array}$ & Bus $^{3}$ & EIS & HASS & Science & Law & $\begin{array}{l}\text { Educ } \\
\text { (HASS) }\end{array}$ & $\begin{array}{c}\text { Nurs } \\
\text { (Science) }\end{array}$ & PhD & Multi & Totals \\
\hline \multicolumn{11}{|l|}{21 to 25} \\
\hline female & 2 & & 6 & 3 & & 1 & 1 & & & 13 \\
\hline male & 1 & 1 & & 1 & 1 & 1 & & & & 5 \\
\hline \multicolumn{11}{|l|}{26 to 30} \\
\hline female & 6 & 1 & 20 & 6 & & 4 & 1 & 1 & 3 & 42 \\
\hline male & & 3 & 4 & 3 & 2 & 1 & & 4 & 2 & 19 \\
\hline \multicolumn{11}{|l|}{31 to 40} \\
\hline female & 6 & 1 & 13 & 7 & & 3 & 3 & 2 & 2 & 37 \\
\hline male & 3 & 9 & 6 & 5 & 1 & & & 1 & 1 & 26 \\
\hline not stated & & & & & & & & & 1 & 1 \\
\hline \multicolumn{11}{|l|}{41 to 50} \\
\hline female & 4 & 1 & 4 & 2 & & 4 & 1 & 2 & & 18 \\
\hline male & 6 & 1 & & 2 & & 1 & & 2 & & 12 \\
\hline \multicolumn{11}{|l|}{ over 51} \\
\hline female & 7 & & 6 & 2 & & 3 & 6 & 2 & & 26 \\
\hline male & 1 & & 1 & 1 & & 1 & & 1 & & 5 \\
\hline Totals & 36 & 17 & 60 & 32 & 4 & 19 & 12 & 15 & 9 & 204 \\
\hline
\end{tabular}

Aside from all being the first in their family to attend university, participants were also invited to identify additional demographic data. In both surveys and interviews, participants could indicate membership of the following groups:

\footnotetext{
${ }^{2}$ Only the 204 who gave their age AND gender are included in this table

${ }^{3}$ Legend: Bus - Business, EIS - Engineering/Information Systems, HASS - Humanities, Arts, Social Sciences, Education (separated from HASS), Nursing (separated from Sciences), Multi - across 2 or more discipline areas
} 
- Student who identifies as Aboriginal or Torres Strait Islander (ATSI)

- Student with a disability (Dis)

- Student from a low socio-economic background (LSES)

- Student from a rural or isolated area (RR)

- Student from a non-English speaking background (NESB)

- Student from a refugee background (Ref)

- Student from a working-class background (WC)

Respondents could elect more than one category and responses indicated the diversity of this cohort, with many identifying multiple categories. For example, just over $45.5 \%$ identified as being from working class backgrounds, whilst $14 \%$ regarded themselves from a low-socio economic environment and just over $9 \%$ were derived from regional, rural and remote areas, as detailed in Figure 1.

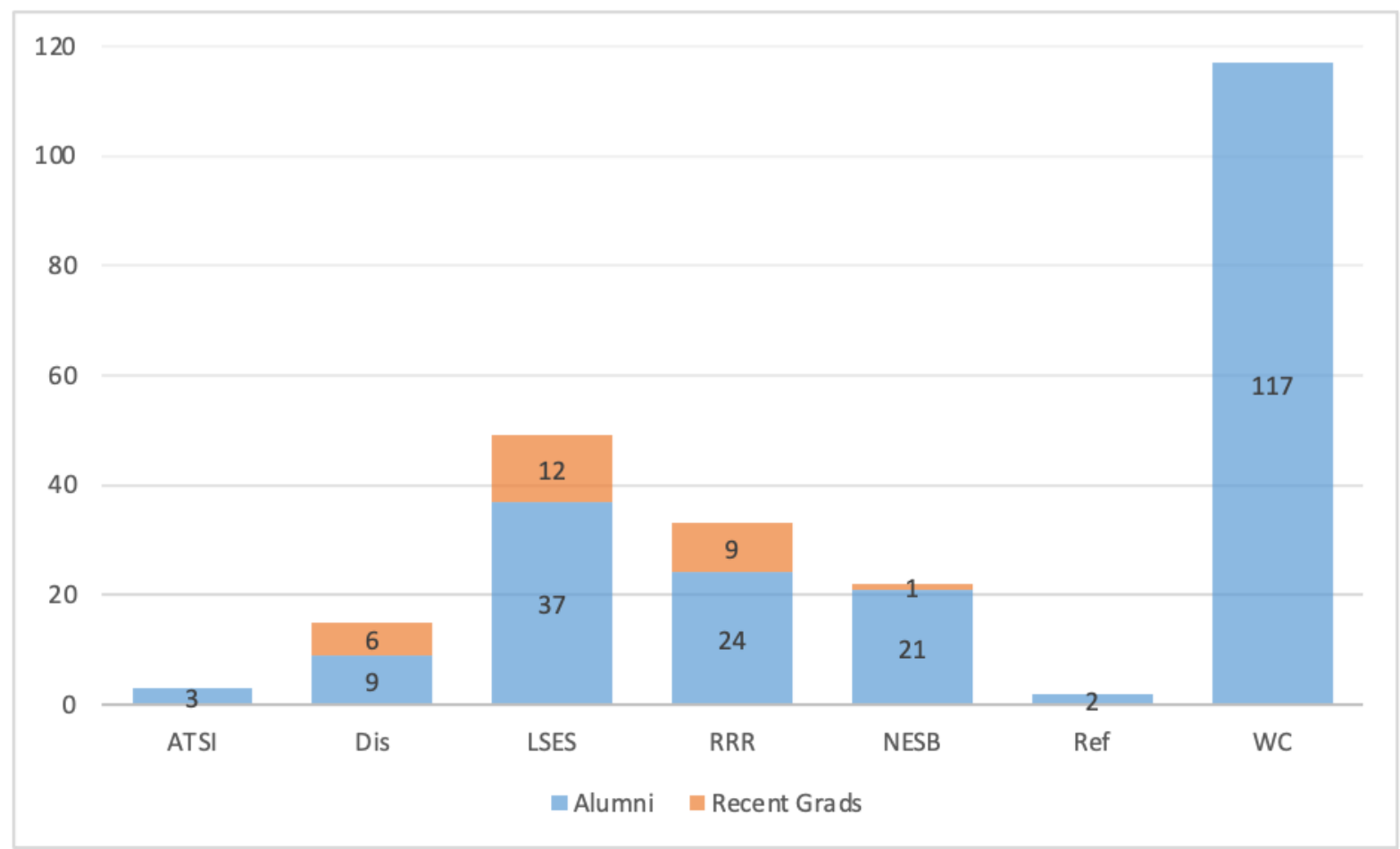

Figure 1: Diverse Backgrounds as Identified by Participants (who could identify more than one category)

The survey and interviews were de identified, and all data, including interview transcripts and survey responses were imported into NVivo12, where line-by-line coding was conducted across all sources. Common themes were identified, and these emergent nodes were carefully investigated using the NVivo Query function, which allowed the data to be 'sliced' according to participant, mode of response and key demographics. The queries run on the project included matrix coding, wordfrequency counts and compound coding searches. Interrogating the data according to different items and perspectives provided a much deeper understanding of the broad field of graduate employment experiences, which was further grounded in the theoretical lens adopted for this study. The rigour of this project was assured by member checking of all interview transcripts, regular investigator meetings to ensure triangulation of data, as well as a detailed audit trail housed in the NVivo12 file that recorded field notes, investigator reflections, codes and themes.

Theoretically, this project drew upon the work of Bourdieusian social theory, focussing on the concept of capital in recognition that the social world is not simply based upon economic wealth, but a complex interplay between non-economic assets, termed cultural capital, for how social groups 
acquire status and indulge in practices of domination and exclusion (Prieur, Rosenlund, \& SkjottLarsen, 2008, p. 46). Importantly, Bourdieu's work recognises that individuals have different capital packages and that different capitals have diverse values depending on the field in which the individual is operating. Certain types of capital result in different forms of advantage so even whilst these participants had achieved the symbolic capital associated with obtaining a degree, it was necessary for them to know how to convert this type of capital successfully within the graduate employment field (Hart, 2012). This research was specifically interested in analysing the ways in which participants both considered the capitals required within the graduate employment field and the ways in which various capitals were drawn upon in the pursuit of employment.

The next sections consider this rich data in relation to three broad themes that emerged from analysis, as follows:

- Unspoken differences in the post-graduate job field.

- Being the 'first' and post-university options.

- Achieving success in the post-graduate field.

To further contextualise the findings and the participants, each quote is followed by brief demographic details of the respondent as indicated in the survey or interview. All quotes from interviews are identified with pseudonyms whilst surveys are identified with a survey number.

\section{Findings and discussion}

\section{Unspoken differences in the post-graduate job field}

Both alumni and recent graduates reflected at length about the various issues and negotiations they encountered when moving from the university sector into graduate employment. These issues were both external and internal to participants; the former largely relating to financial issues and geography. Most respondents experienced some level of economic distress and as a result needed to work to support their academic pursuits. However, this restricted access to material resources impacted not only their experiences within the degree but also the choices they had after graduation:

Lack of finances, difficulties finding employment. Moving 16 hours away to a remote rural town just to obtain employment in my area of study. Solved the finances and employment problem, caused many others including isolation, depression, insomnia and anxiety (Female, 21-25, Nursing, WC, graduated 5yrs, \#694).

Many graduates also experienced geographic limitations. Being willing to move for work was a requirement for a number of the alumni and graduates, and often this movement was expressed in terms of loss, a necessary but somewhat unwelcome decision, the following quote speaks to these challenges:

The painful truth is that living in a regional area means that my qualifications are not directly relevant to the work that is available here...so the only way to achieve any type of career progression...is to relocate to a metropolitan area - something I am unwilling to do while my children are in school. It is a difficult thing to reconcile at times (Female, 31-40, Arts, RR, WC, LSES, graduated 2yrs, \#87).

Both the financial and geographic restrictions faced by graduates from equity backgrounds has been considered in the literature (Burke, et al., 2017; Cardak et al., 2017; O'Shea \& Delahunty, 2018; Pollard, 2018) but what is less considered are the invisible or 'unspoken' issues graduates from more diverse backgrounds may encounter in the employment field. The respondents in this study

\footnotetext{
${ }^{4}$ All surveys were anonymous but each was allocated a number to which demographic data and responses are attached.
} 
reflected upon a number of issues that were experienced at a more personal or embodied level. Despite the diversity of participants, commonality of experience was noted.

One of the key areas identified was a lower sense of belonging that both impacted on seeking employment in the field and workplace experiences. Lower levels of belonging have been noted in relation to FiF students during the transition into, and initial movement through, university (Longwell-Grice, et al., 2016; Longwell-Grice \& Longwell-Grice, 2008; Martin, 2015) but little is known about how these impact on outcomes after graduating. The graduates and alumni reflected upon a pervasive 'imposter syndrome', often discussing how this affected employment outcomes or even perceived opportunities.

Aleisha, for example, spoke at length about perceived but unspoken 'differences' to those around her. Aleisha had returned to university studies later in life, had a young family and described herself as not very worldly and from a background that didn't include broad cultural things. In the final stages of a post-graduate teaching degree she described her experiences of working within schools, recognising these perceived limitations keenly in her current employment, explaining:

sometimes now where I'm working, listening to teachers that maybe came from more affluent kinds of families - they're talking about when they did overseas study trips or that they holidayed in Sweden, just all these things where they have that global experience I suppose. I don't really have anything to connect with that and ... I think that's something that I am lacking (Aleisha, 40, Education, NESB).

This theme of feeling like an imposter also occurred across a range of responses in the alumni survey. Such perceptions appeared to be an inherent constraint that did not necessarily diminish even after gaining employment. There was a sense of shame in some of the descriptions, in that perceptions of difference were almost something that needed to be hidden, or internalised and never spoken about. This is summed up by one survey respondent who explained that the imposter syndrome was persistently internalised as a fear of being exposed as a fraud (Female, +51 , Business, WC, graduated $1 \mathrm{yr}, \# 130$ ). Another described feeling like I cheated my way in and that I don't really have the smarts to be here (Female, 31-40, Business, graduated 12 yrs, \#208). Such low levels of belonging did not necessarily diminish after gaining a degree. One respondent described feeling like an outsider if you do not have the right background and then goes onto explain that I cannot magically summon an acceptable backstory and a supportive environment just by graduating - those pressures remain and take a toll (Female, 41-50, Science, Dis, WC, graduated 17yrs, \#70).

Undoubtedly, educational history and family background played into this sense of difference or not belonging. The next section explores in more depth what participants perceived as being the impacts of their FiF status on their choices and opportunities after graduation.

\section{Being the 'first' and post-university options}

As previously mentioned, participants in this study self-identified as being the first in their immediate family to attend university. This status impacted individuals in different ways but one key theme that emerged was in relation to access or understanding of certain knowledges or capitals, referred to as 'insider knowledges'. We use the term 'insider knowledge' to convey understanding or familiarity about certain ways of behaving that are often regarded as being accepted or taken for granted, and these assumptions are rarely made explicit. Not having this type of knowledge can lead to levels of inequity, impacting individual's success or achievement within different domains (Crozier, Reay, Clayton, Colliander, \& Grinstead, 2008; O'Shea, 2020). In this study, the term (insider knowledge) is used to refer to implicit knowledge capitals that may influence the experiences of FiF students within the graduate employment market.

Focussing on the alumni surveys, comments included reflecting on not having a 'knowledgeable other' to ask questions of or obtain advice from. This was a recurrent theme as many lamented the limited guidance they received, particularly as they moved from university study and attempted to break into the employment market. The knowledges (or lack thereof) varied from not having applied 
skills such as preparing for an interview or writing a resume right through to having limited understanding about the inner workings of graduate recruitment, including the hyper competitive nature of this environment. For these alumni, such knowledges were perceived as being primarily sourced or derived from family members rather than the university itself. Being the first to attend university translated into a gap or lack which was regarded as disadvantaging the individual learner:

I think had someone else from my family followed the path to completion I may have had a better insight into what going to uni means, rather than subscribing on the uni business model of 'a pathway to success' (Male, 31-40, Science, WC, graduated 2 yrs, \#101).

I had no family members who could help advise or explain the landscape. I had very little understanding of how the corporate world worked. I was very much trying to piece together this information on my own (Female, 31-40, Arts, WC, graduated $10 \mathrm{yrs,} \mathrm{\# 193).}$

For the alumni in particular, many of whom had spent significant time navigating and negotiating the graduate landscape, their status of being the 'first' had clear repercussions for the character and nature of their job-seeking experiences. Without a suitable 'guide on the side', individuals floundered initially, requiring additional time and effort to develop necessary understandings of a somewhat alien environment.

Interestingly, not having this knowledge was regarded as being a personal limitation, rather than reflecting university practices or the degree content. In many of the responses, it was clear that the responsibility for understanding what came next was regarded as being an individual rather than an institutional one:

I was very ignorant in what came after (Female, 26-30, Business, WC, graduated $6 \mathrm{yrs,}$ $\# 150$ ).

In my world I literally never met anyone who had a degree (Female, 51, Education, NESB, WC, graduated 20 yrs, \#239).

Importantly, not all of the participants perceived such gaps in knowledge or limited belonging in negative terms, with some regarding this as being an incentive to work harder and to persist in a competitive graduate market. The next section provides detail of how success was both conceptualised and enacted in the field, with specific reference to what was regarded as assisting this process.

\section{Achieving success in the post-graduate field}

Not everyone perceived 'being the first' in negative terms. There was also recognition that this status could positively impact on the ways in which employability was enacted. While recognising that the access to necessary insider knowledge might be curtailed, respondents also indicated that FiF status could provide additional traits or capitals that assisted in securing work. This was, however, often recognised retrospectively. Wade $(22$, Science, graduated $2 y r s)$ explained that as the first in his family, he had been required to kind of carve your own way through and find the answers to your questions without any guiding hands perhaps. For Wade, this was ultimately a positive experience as he reflected how it's made me a more self-sufficient person and I'm grateful for it. In a similar vein, Sophie explained that as a first in family student she had to go that extra mile to get your leg in the door. Again this additional effort was regarded as affirming and positive as she explained, once you do get your leg in the door, you're a much more competitive candidate and because you've worked for it, you kind of value it more, I guess (Sophie, 20, Science, Final Year).

Success for these FiF participants was not an inevitable outcome of university study. Instead, being successful often seemed to require something more than what was expected of their second or third-generation peers. Molly (39, Social Work) perceived her success in the field as being derived from her 'resilience' and 'competitiveness' that she had acquired through life experience, also echoed by some survey respondents: 
Being first in family and from low [socio-economic status], I had limited financial and family support. I am stronger, more resilient and competitive in the field as I have life experience (Molly, 39, Social Work, LSES, graduated 1yr).

Being poor - straight out of university I worked minimum- or low-wage jobs at first. Thus, I had to continue living in shared housing and be quite creative...it took me a while to see that my variety of experiences [was] giving me valuable skills (Female, 31-40, Science/Education, NESB, graduated 5yrs, \#153).

Data presented in these sections indicates that being the first in the family to attend university had complex and far reaching repercussions. This FiF status was perceived in duality: providing capitals that both limited and assisted individuals within the employment field. Importantly, these findings show that this status is recognised as something which clearly impacts on educational and employment outcomes, yet our understandings of this population remains limited across the student life cycle. The final part of this paper will consider these findings in more depth, particularly considering the ways in which educational institutions might do things differently and thereby ensure a more equitable post-graduate environment.

\section{Conclusions and recommendations}

The findings indicate how the Australian post-graduation landscape remains a highly differentiated one: experiences of this field vary according to educational and biographical background. While this paper offers a 'snapshot' of this environment and is explicitly focused on those who were the first in their family to attend university, it clearly articulates the differences and delineations in expectations and knowledge of the employment field compared to what might be assumed or expected. We know that Australia is not unique in having such differences or delineations in knowledge levels, with experiences of diverse cohorts similarly differentiated internationally (Bathmaker, 2021; Lehmann, 2021).

Many of the alumni and recent graduates reflected upon perceived 'gaps' in their knowledge which led many to feeling a sense of being 'different' to their peers. Like the working-class participants in Bathmaker's UK study, there were references to an implicit 'social capital advantage' that pervaded this employment field (Bathmaker et al., 2013, p. 737). Bourdieu (1986) identifies how economic and non-economic criteria can work together to create distinct social status and hierarchies. For these FiF participants there seemed to be certain knowledges or 'ways of being' that were implicit in the graduate market place; such forms of knowledge or 'being' regarded as more legitimate than others (Bourdieu, 1986). This leads to the first recommendation from this study which is the need to explicitly unpack the codified knowledge of the graduate work environment and the implicit practices of job seeking. This deliberate unpacking should also be accompanied by policy that clearly articulates how students, particularly equity learners, will be supported during transition out of university and as they navigate the employment field. Given the global employment and economic climate, the responsibility of universities can no longer cease once students achieve their qualification, instead this role must be expanded to include support and advice beyond graduation.

The stratified nature of the employment market as identified by participants is perhaps unsurprising, as we know that the higher education environment is equally delineated. Reay (2016) refers to both the process of getting into university and the experiences of different cohorts within the higher education realm as powerfully classed (p. 4). Similarly, Naidoo explains:

The higher education system ... reproduces the principles of social class and other forms of domination under the cloak of academic neutrality...in this way, universities contribute to the 'misrecognition' and therefore 'naturalization' of structures of domination (Naidoo, 2004, p. 460).

However, the data in this study explicitly articulates how such differentiation travels with equity bearing students beyond graduation. Clearly employment choice for a number of these graduates 
was, similar to the university students in Reay's UK study (2016), better described as an uncertain process of finding out what you cannot have, what is not open for negotiation, and then looking at the few options left (p. 11). These limitations, however, did not necessarily preclude certain employment options but rather necessitated either a reassessment of desired outcomes or a capacity to put in additional, often symbolic, work, into achieving these goals.

Importantly, this additional work was not always perceived negatively; instead the ways in which these FiF learners reflected upon extra effort was also characterised by a sense of pride. We are not, however, suggesting that this additional work should be welcomed nor represent the necessary 'deserving' nature of this population. Instead, this study points to the qualities that these participants reflected upon - determination, resilience and fortitude - as being rarely acknowledged or valued across university settings. Many Fif students, particularly those who are older, may arrive at the institution replete with a rich variety of experiences or 'experiential capital' that they can draw upon during and after studies (O'Shea, 2018). However, these types of capital are clearly not in the 'currency' that is valued and celebrated within most higher education settings, not only in Australia but in other countries as well. Hence, the second recommendation is the need to reaffirm the strengths that learners arrive with by embedding these within university policy and practices. Importantly, the value of these existing capitals needs to be made explicit to employers, how such capitals translate into an employability framing should be clearly communicated across all stakeholders in the university to work transition.

Finally, the data presents some key learnings for the global employment landscape that continues to be buffeted by the repercussions of the COVID pandemic. The participants in this study clearly articulated how unprepared they were for the lengthy and difficult route to work in their field of study, and as the statistics indicate, underemployment amongst graduates is rife. To ensure that students are making informed decisions and are equally avoiding assumptions about university as the pathway to success (as one respondent described), the need for unbiased and clear communication of future job prospects is required. We propose that independent university peak bodies provide realistic and rigorous cost-benefit analyses for different fields of study that are accessible to all individuals considering university studies. In the coming years more than ever, future students will need to make informed choices about the qualifications pursued including the longitudinal 'opportunity costs' of gaining a degree.

\section{Acknowledgement}

The authors gratefully acknowledge that this study was funded by the National Centre for Student Equity in Higher Education (NCSEHE). Further details and Fellowship report are available at:

https://www.ncsehe.edu.au/publications/post-graduation-outcomes-first-family-university/

\section{References}

Akkermans, J., Richardson, J., \& Kraimer, M. (2020). The Covid-19 crisis as a career shock: Implications for careers and vocational behavior. Journal of Vocational Behavior, 119, Article No. 103434. Retrieved from https://doi.org/10.1016/j.jvb.2020.103434

Allen, K., Quinn, J., Hollingworth, S., \& Rose, A. (2013). Becoming employable students and 'ideal' creative workers: Exclusion and inequality in higher education work placements. British Journal of Sociology of Education, 34(3), 431-452. doi:10.1080/01425692.2012.714249

Ashley, L., Duberley, J., Sommerlad, H., \& Scholarios, D. (2015). A qualitative evaluation of non-educational barriers to the elite professions. Retrieved from https://dera.ioe.ac.uk/23163/1/A qualitative evaluation of noneducational barriers to the elite professions.pdf

Ball, S., Davies, J., David, M., \& Reay, D. (2002). 'Classification' and 'Judgement': Social class and the 'cognitive structures' of choice of Higher Education. British Journal of Sociology of Education, 23(1), 51-72.

Bathmaker, A-M. (2021). Constructing a graduate career future: Working with Bourdieu to understand transitions from university to employment for students from working-class backgrounds in England. 
European Journal of Education: Research, Development and Policy, 56(1), 78-92.

https://doi.org/10.1111/ejed.12436

Bathmaker, A.-M., Ingram, N., \& Waller, R. (2013). Higher education, social class and the mobilisation of capitals: recognising and playing the game. British Journal of Sociology of Education, 34(5-6), 723-743. doi:10.1080/01425692.2013.816041

Bourdieu, P. (1986). The Forms of Capital. In J. Richardson (Ed.), Handbook of theory and research for the sociology of education (pp. 241-257). New York: Greenwood Press.

Bradley, D., Noonan, P., Nugent, H., \& Scales, B. (2008). Review of Australian higher education: Final report [Bradley Review]. Canberra: Aust. Govt. Retrieved from https://www.voced.edu.au/content/ngv\%3A32134

Burke, P., Bennett, A., Bunn, M., Stevenson, J., \& Clegg, S. (2017). It's about time: Working towards more equitable understandings of the impact of time for students in higher education. WA: NCSEHE. Retrieved from: https://www.ncsehe.edu.au/publications/its-about-time-working-towards-more-equitableunderstandings-of-the-impact-of-time-for-students-in-higher-education/

Cardak, B., Brett, M., Bowden, M., Vecci, J., Barry, P., Bahtsevanoglou, J., \& McAllister, R. (2017). Regional student participation and migration: Analysis of factors influencing regional students participation and internal migration in Australian higher education. WA: NCSEHE. Retrieved from:

https://www.ncsehe.edu.au/publications/regional-student-participation-and-migration-analysis-offactors-influencing-regional-student-participation-and-internal-migration-in-australian-higher-education/

Crozier, G., Reay, D., Clayton, J., Colliander, L., \& Grinstead, J. (2008). Different strokes for different folks: Diverse students in diverse institutions - experiences of higher education. Research Papers in Education, 23(2), 167-177.

Drane, C., Vernon, L., and O'Shea, S. (2020). The impact of 'learning at home' on the educational outcomes of vulnerable children in Australia during the COVID-19 pandemic. Retrieved from https://www.dese.gov.au/document/professor-sarah-o-shea-national-centre-student-equity-highereducation

Edwards, D., \& McMillan, J. (2015). Completing university in a growing sector: Is equity an issue? Melbourne, Australia: ACER. Retrieved from https://research.acer.edu.au/cgi/viewcontent.cgi?article=1045andcontext=higher education

FYA. (2018). The New Work Order Report Series. Retrieved from Melbourne: https://www.fya.org.au/report/new-work-order-summary/

FYA. (2020). The new work standard: How young people are engaging with flexible work. . Retrieved from https://www.fya.org.au/our-research-2/

Hart, C. (2012). Aspirations, education and social justice: Applying Sen and Bourdieu. London, UK: Bloomsbury. HESA. (2017). Destinations of Leavers from Higher Education in the United Kingdom for the academic year 2015/16. Retrieved from https://www.hesa.ac.uk/news/29-06-2017/sfr245-destinations-of-leavers\#

HESA. (2018). Destinations of Leavers from Higher Education Longitudinal survey. Retrieved from https://www.hesa.ac.uk/data-and-analysis/publications/long-destinations-2012-13

Interns Australia. (2018). Interns Australia welcomes labor's decision to ban unpaid internships. [Press release] Lehmann, W. (2021) Conflicts and contentment: Case study of the social mobility of working class students in Canada. European Journal of Education: Research, Development and Policy, 56(1), 41-52. Available at: https://doi.org/10.1111/ejed.12431

Longwell-Grice, R., Adsitt, N. Z., Mullins, K., \& Serrata, W. (2016). The first ones: Three studies on firstgeneration college students. NACADA Journal, 36(2), 34-46.

Longwell-Grice, R., \& Longwell-Grice, H. (2008). Testing Tinto: How do retention theories work for firstgeneration, working-class students? Journal of College Student Retention: Research, Theory and Practice, 9,(4), 407-420.

Luzeckyj, A., King, S., Scutter, S., \& Brinkworth, R. (2011). The significance of being first: A consideration of cultural capital in relation to 'first in family' student's choice of university and program. A Practice Report. The International Journal of the First Year in Higher Education, 2(2), 91-96.

Marginson, S. (2016). The worldwide trend to high participation in higher education: Dynamics of social stratification in inclusive systems. Higher Education, 72, 413-434.

Martin, G. (2015). 'Tightly wound rubber bands': Exploring the college experiences of low-income, firstgeneration White students. Journal of Student Affairs Research and Practice, 52(3), 275-286. doi:10.1080/19496591.2015.1035384

Mehta, S., Newbold, J., \& O’Rourke, M. (2011). Why do first-generation students fail? College Student Journal, 45(1), 20-35. 
Montacute, R. (2018). Internships - unpaid, unadvertised, unfair. Research Brief, Edition 20, 1-6. Available at: https://www.suttontrust.com/wp-content/uploads/2018/01/Internships-2018-briefing.pdf

Moreau, M. P., \& Leathwood, C. (2006). Balancing paid work and studies: Working (-class) students in higher education. Studies in Higher Education, 31(1), 23-42.

Naidoo, R. (2004). Fields and institutional strategy: Bourdieu on the relationship between higher education, inequality and society. British Journal of the Sociology of Education, 25(4), 457-471.

NCES. (2018a). Employment and unemployment rates by educational attainment. Retrieved from https://nces.ed.gov/programs/coe/pdf/coe cbc.pdf

NCES. (2018b). Employment outcomes of Bachelor's degree recipients. Retrieved from https://nces.ed.gov/programs/coe/pdf/Indicator SBC/coe sbc 2015 11.pdf

Norton, A. (2020). Graduate employment prospects during the COVID-19 recession. Retrieved from https://andrewnorton.net.au/2020/03/30/graduate-employment-prospects-during-the-covid-19recession/

OECD (2001). Economics and finance of lifelong learning. Paris: Organisation for Economic Co-operation and Development.

O'Shea, S. (2016). Avoiding the manufacture of "sameness": First-in-family students, cultural capital and the higher education environment. Higher Education, 72(1), 59-78.

O'Shea, S. (2018). Considering the cultural strengths of older first-generation university students In A. Bell and L.J. Santamaria (Eds.), Understanding Experiences of first-generation university students: Culturally responsive and sustaining methodologies. (pp. 143-165). UK: Bloomsbury Publishing.

O'Shea, S. (2020). Crossing boundaries: Rethinking the ways that first-in-family students navigate 'barriers' to higher education. British Journal of Sociology of Education. 40 (1), 95-110. https://doi.org/10.1080/01425692.2019.1668746

O'Shea, S., and Delahunty, J. (2018). Getting through the day and still having a smile on my face! How do students define success in the university learning environment? Higher Education Research and Development, 37(5), 1062-1075.

O'Shea, S., May, J., Stone, C., and Delahunty, J. (2017). First-in-Family Students, University Experience and Family Life: Motivations, Transitions and Participation. London: Palgrave Macmillan.

Pascarella, E., Pierson, C., Wolniak, G., \& Terenzini, P. (2004). First-generation college students: Additional evidence on college experiences and outcomes. The Journal of Higher Education, 75(3), 249-284.

Patfield, S., Gore, J., \& Weaver, N. (2021). On 'being first': the case for first-generation status in Australian higher education equity policy. Australian Educational Researcher. https://doi.org/10.1007/s13384-02000428-2

Pitman, T., Roberts, L., Bennett, D., \& Richardson, S. (2019). An Australian study of graduate outcomes for disadvantaged students. Journal of Further and Higher Education, 43(1), 45-57. doi:10.1080/0309877x.2017.1349895

Pollard, L. (2018). Remote student university success: An analysis of policy and practice. WA: NCSEHE. Retrieved from: https://www.ncsehe.edu.au/publications/remote-student-university-success-analysispolicy-practice/

Prieur, A., Rosenlund, L., \& Skjott-Larsen, J. (2008). Cultural capital today: A case study from Denmark. Poetics, 36(1), 45-71.

Purcell, K., P. Elias, G. Atfield, H. Behle, R. Ellison, \& D. Luchinskaya (2013). Transitions into employment, further study and other outcomes. Futuretrack Stage 4 Report. Warwick: Higher Education Career Services Unit.

QILT. (2018). 2018 Graduate outcomes survey - longitudinal (GOS-L) medium-term graduate outcomes. Retrieved from https://www.qilt.edu.au/about-this-site/graduate-employment

QILT. (2019). 2018 Graduate outcomes survey: National report. Retrieved from https://www.qilt.edu.au/docs/default-source/gos-reports/2018-gos/2018-gos-national-report2018.pdf?sfvrsn=a729e33c 4

Reay, D. (2016). Social class in higher education: Still an elephant in the room. In J. Cote \& A. Furlong (Eds.), Routledge handbook of the sociology of higher education (Ch. 12). Abingdon: Routledge.

Reay, D., David, M., \& Ball, S. (2001). Making a difference?: Institutional habituses and higher education choice. Sociological Research Online, 5(4), 14-25. Retrieved from http://www.socresonline.org.uk/5/4/reay.html

Reidy, T. (2020, 10 April). 'Recruitment is on hold': The students graduating into the Covid-19 recession. The Guardian. Retrieved from https://www.theguardian.com/education/2020/apr/10/recruitment-is-on-holdthe-students-graduating-into-the-covid-19-recession

O'Shea, S., Groves, O., \& Delahunty, J. (2021). '...having people that will help you, that know the ropes and have walked that road before you': How does first in family status impact graduates in the employment field? Journal of Teaching and Learning for Graduate 
Richardson, S., Bennett, D., \& Roberts, L. (2016). Investigating the relationship between equity and graduate outcomes in Australia. WA: NCSEHE. Retrieved from https://www.ncsehe.edu.au/wp-

content/uploads/2016/04/Investigating-the-Relationship-between-Equity-and-Graduate-Outcomes-inAustralia.pdf

Roulin, N., \& A. Bangerter (2013). Students' use of extra-curricular activities for positional advantage in competitive job markets. Journal of Education and Work, 26(1), 21-47.

Shergold, P., Calma, T., Russo, S., Walton, P., Westacott, J., Zoellner, D., \& O’Reilly, P. (2020). Looking to the Future: Report of the review of senior secondary pathways into work, further education and training.

Australia: Education Council. Retrieved from https://www.pathwaysreview.edu.au/

Spiegler, T., \& Bednarek, A. (2013). First-generation students: What we ask, what we know and what it means: An international review of the state of research. International Studies in Sociology of Education, 23(4), 318-337.

Universities Australia. (2020). The crucial role of universitites in a coronavirus recovery. Retrieved from https://www.universitiesaustralia.edu.au/media-item/the-crucial-role-of-universities-in-a-coronavirusrecovery/

Universities New Zealand. (2018). New Zealand's Universities Key Facts and Stats [Press release]. Retrieved from https://www.universitiesnz.ac.nz/sites/default/files/uninz/documents/UNZ\%20New\%20Zealand\%27s\%20Universities\%20Key\%20Facts\%20\%26\%20Stats\%20Nov \%202018 0.pdf 